\title{
O lugar e a cena, o literal e o figurado
}

O Teatro da Vertigem já consolidou uma linha avançada de pesquisa teatral cujo traço marcante é a encenação que, dialogando com dramaturgos que entrelaçam sua fatura com o processo de preparação do espetáculo, se apoia e se cria a partir de um espaço já estruturado que carrega uma identidade no seio da malha urbana. Há a escolha de espaços institucionais dotados de conotações específicas (igreja, hospital, prisão, edifício num local emblemático da verticalização da cidade). $E$ há a escolha de travessias que exploram a relação entre cena aberta e canais de circulação que, por sua estrutura feita de camadas superpostas da história, ensejam uma relação especial entre o núcleo temático da peça e a experiência sensorial, corporal e de fricção com o ambiente implicadas na travessia. $O$ dado constante nesta exploração de espaços é a interação peculiar de atores e espectadores num convívio que não abole de vez as fronteiras do jogo de cena, mas as desloca de modo a fazer elenco e plateia partilharem, não do mesmo modo, o senso do estranho familiar imposto pelo ambiente. Este se faz experiência de imersão e vai além dos olhos e ouvidos, seja nos confinamentos que aguçam um imaginário de experiências limite , seja na circulação a céu aberto em que o traçado linear, de água ou de asfalto, apenas traz um senso de direção ilusória para uma deriva cuja tônica é a memória da catástrofe e a vivência de seus desdobramentos recentes na morte do rio Tietê e no dinamismo fashion de um bairro, o "novo" Bom Retiro que dissolveu culturas e se vê cristalizado num Shopping Center, festa da forma-mercadoria e da exploração do trabalho nos moldes das sweat-shops de outras décadas novaiorquinas, agora em sua versão paulistana.

\footnotetext{
1 Possui graduação em Comunicação Social com Habilitação em Cinema pela Universidade de São Paulo (1970), mestrado em Letras (Teoria Literária e Literatura Comparada) pela Universidade de São Paulo (1975), doutorado em Letras (Teoria Literária e Literatura Comparada) pela Universidade de São Paulo (1980) e doutorado em Cinema Studies - New York University (1982). Professor associado da Universidade de São Paulo. Tem experiência na área de Comunicação, com ênfase em Cinema, atuando principalmente nos seguintes temas: cinema, cinema brasileiro, cinema moderno e contemporâneo, teoria e história do cinema, cinema e teatro, cinema e pintura, cinema e fotografia, cinema e fotografia.
} 
Quero ressaltar aqui a forma como estas encenações-travessias inscrevem o tempo histórico em seu movimento; ou seja, como essa exploração do espaço consegue atravessar certas camadas do tempo sedimentado na crosta da cidade e torná-las experiência sensível porque, dada a natureza da imersão, o teatro, a geografia urbana e a economia se contaminam reciprocamente. Meu foco de atenção se dirige aos pontos de partida e de chegada da encenação em BR-3 e Bom Retiro: 958 metros. Nas duas encenações, há um ponto de partida na configuração do espaço cênico que sugere uma estrutura associada à agitação cotidiana da cidade. Em $B R-3$, temos o ponto de regulagem do fluxo das águas no encontro do Tietê com o Pinheiros, onde há também um emaranhado de pontes e viadutos; em Bom Retiro, temos o Shopping Center e suas lojas trazendo os sinais de um comércio em pleno vigor. $O$ essencial é que, no momento em que encontramos o elenco, e a cena toma lugar, esse ponto de partida esteja em estado de inércia ou de baixa circulação, o que favorece uma relação noturna cuja dimensão onírica, fantasmática, faz do concreto das comportas do rio e das pontes, como também mercadorias das vitrines das lojas, um campo de projeções variadas, um imaginário que convive com o foco maior da atenção avivado pela movimentação dos atores (e espectadores) que vai instituindo a Cena - o espaço efetivamente apropriado pela ação do elenco - e tratando de dominar a extensão desse décor e seus pontos de fuga, embora faça parte do jogo uma certa reposição do pergunta : nesta extensão, onde está o núcleo da Cena?

A interação com os atores vai definindo um código que o barco-mãe de $B R-3$, na diegese, a igreja de que somos fiéis (ou o cinema?) e onde permanecemos, desde o princípio, junto a uma personagem-narradora central, a Evangelista. Tal condição estabiliza (nem tanto) um ponto de vista que se confronta com a variedade de espaços de ação dos atores (comportas, barcos satélites, margens do rio) que vai ganhando novas feições à medida que seguimos o curso do rio, contra a corrente, o que na minha leitura será decisivo. Em Bom Retiro, a estrutura do shopping compõe um espaço que, embora ordenado, ultrapassa os limites da cena, mas esta se garante como foco maior ao seguirmos as indicações dos atores, inclusive com chamados do tipo "sigam-me", pois temos a moça (dentro e na interface da cena) que cumpre um cerimonial típico da visita guiada cujo horizonte é expor o que é subjacente à energia dos fetiches do Shopping, a face invisível no seu regime diurno. 


\section{A morte do rio}

Brasília, Brasilândia (periferia de São Paulo) e Brasiléia (Acre) dominam o espaço diegético de $B R$-3, o mundo das andanças de Jovelina (depois Wanda), seu filho Jonas e sua família. São os espaços simbólicos que configuram as três estações do seu percurso migratório de personagens que, atingidos de todo lado pelas vicissitudes de uma condição de pobreza material reiterada ao longo da travessia, vivem um imaginário alimentado por impulso messiânico de salvação que, enredado em tramas de vingança e assassinatos, impregna de forma crescente a cena para compor o eixo de uma busca cheia de sincretismos e seitas que, ao invés da redenção, leva à catástrofe. De uma geração a outra, tal impulso faz o drama convergir para a sede do culto instituído por Jonas, que fugiu de Brasilândia para o Acre. No final, atraídos por motivos, subterfúgios e caminhos distintos, os dois filhos que ele mal conhece chegam ao território do pai no mesmo momento, e o encontro fortuito dá ensejo à violência e vem completar a dança da morte que pontua a saga familiar. "Tudo que toco morre", eis o lamento final de Jonas na consumação de seu fracasso após um percurso feito de guerras de traficantes e guerras de igrejas, figuras trocando de papéis numa ciranda de nomes falsos, ações que alcançam resultados inversos ao objetivo proclamado, narradores não confiáveis que entrelaçam suas mentiras de modo a produzir efeitos que encontram um exército de crédulos prontos para lhes atribuir sentido.

O caminho em direção ao desastre enlaça personagens instituídos por uma fala e um jogo de máscaras, luzes e gestos que, de começo a fim, compõe um movimento desconstrutivo que acentua a instabilidade da relação entre fato e discurso, entre fé no sentido das palavras e sua progressiva dissolução, tudo a problematizar o estatuto da cena visível. Neste dinamismo, a escolha do espaço atravessado pelo teatro (cena e observadores da cena) e a forma como somos todos imersos (por bom tempo) no leito do Tietê vem compor mais uma dimensão do estranho-familiar que nos cerca por todos os lados, incluindo as luzes dos veículos que seguem pelas vias expressas, acima de nós ali imantados pela placidez do rio canalizado, a ouvir o murmúrio das águas, a sentir o mau cheiro, a ver os detritos, as bocas de esgoto a emporcalhar o rio em cada parada que corresponde às estações do drama quando encenado nas margens. Ponto decisivo, a experiência de singularização, estranhamento do já conhecido se torna mais forte, mais eficaz, mais poético, porque se trata deste lugar que, fora da diegese (a história que acompanhamos tem como referência outros espaços e cobre alegoricamente o Brasil todo), 
se impõe a partir desta imersão que nos afeta, e muito. De modo que a cena, em sua dimensão site specific, constrói um paralelismo que marca toda a travessia. Se a fábula se compõe para a desconstrução de um mito (o centrado na figura de Jonas), a cena se compõe para a desconstrução de outro mito que é exterior à fabula narrada, uma vez que nossa navegação não se efetiva para tornar as figuras do barco ou do rio metáforas-clichê, evocação genérica da "jornada da vida" ou do paradigma da peregrinação. O que importa aqui é o próprio rio Tietê, enquanto rio Tietê, núcleo desse outro mito engastado na grande narrativa concebida pela elite do café a partir do final do século XIX e reiterada por todas as novas facetas da classe dominante paulista ao longo do século XX; a saber, o mito do bandeirismo como matriz do espírito empreendedor de seus supostos herdeiros com seus desdobramentos no avanço da eletricidade e da indústria que fez da cidade banhada pelo rio a exaltada "locomotiva do país", a terra da promissão. Pois bem, nossa travessia acompanhando a cena de BR-3 põe em relevo o que ficou submerso na história, o enorme movimento predatório - no plano social e ambiental - implicado nesse avanço que começou no período colonial e se estende até hoje.

Quando me refiro a esta desconstrução do mito paulista não me apoio apenas no teor da travessia, esta penosa experiência de maior intimidade com o esgoto, o lixo, a morte do rio, a onipresença das marginais, mas também na fundamental relação entre o ponto de partida e o de chegada. O desfecho desastroso da fábula (a morte como telos, a dissolução da esperança) se encena, e isto se dá pela primeira vez na jornada, em espaço fechado, abaixo do convés, quando perdemos de vista o rio e tudo o mais que podíamos ver no caminho. Consumado o desenlace funesto, somos conduzidos de volta ao convés onde terminará a encenação. Ao sair, percebemos que estamos debaixo das alças de concreto que saem da Rodovia dos Bandeirantes e fazem uma cruz bem em cima do rio para caírem nas marginais, ponto em que, do outro lado do rio, começa a rodovia e há o monumento que a 'sacraliza' dentro deste espírito de continuidade com o mito bandeirante que marcou a nomeação das estradas para o Oeste (a menos do caso do Marechal Castelo Branco, e pour cause). Temos neste final, quando nosso olhar re-encontra o espaço aberto, o gesto forte da mise-en-scène que coroa nosso movimento contra a corrente do rio, ou seja, contra a direção tomada pelo movimento dos caçadores de índios e de ouro ajudados pela anomalia do Tietê que, ao invés de ir em direção ao mar, corre para o interior até encontrar o rio Paraná, tendo facilitado a navegação para o oeste tão decantada porque expandiu o território nacional. 
BR-3 alcança um extraordinário rendimento na composição dessa homologia entre o movimento de sua fábula e a nossa travessia por este lugar tão emblemático explorado na encenação. Sela, deste modo, o entrelaçamento da dramaturgia do texto e a dramaturgia da travessia que permite o salto de um imaginário a outro e faz valer o embate com este lugar que condensa um significado histórico que se imprime, nessa chave da catástrofe, em nossa própria experiência da encenação como um diagnóstico do que se consumou na história da cidade tal como se figura na morte do rio, raramente trazida à percepção de forma tão aguda.

\section{Shopping Center versus Casa do Povo}

A Casa do Povo, na Rua Três Rios, é o ponto final da caminhada pelo Bom Retiro (o nome dispensa comentários), num percurso que começou no Shopping Center dominado pelas confecções que identificam uma atividade já tradicional que mudou de função e de escala desde que passou ao controle dos migrantes coreanos que substituíram os membros da colônia judaica na condução desta indústria associada ao bairro. Como já observei, o shopping é o momento de exposição de um estado de coisas referido à vida contemporânea que se apóia na visita noturna ao espaço a esta hora inerte como lugar de troca, mas habitado pelas imagens que evocam as costureiras bolivianas em seu trabalho contínuo, que não tem hora, pois mão de obra de migrantes ilegais tratados como semi-escravos, imagens que se entrelaçam com as de uma estação de rádio interessada em manter as pessoas acordadas e cujas mensagens, na típica histeria superlativa do meio, trazem a sonsa ou cínica euforia aos nossos ouvidos. Passeamos por uma fantasmagoria feita destas mensagens e evocações, com ênfase para a introdução da figura da mulher-manequim como cristalização do fetiche associado ao sistema da moda. Em cena, tal figura compõe um corpo-objeto compósito surreal, pode-se dizer literalmente surrealista no espírito das exposições deste movimento nos anos 30. Posta em movimento, a figura produz um efeito singular que condensa, neste modo de ser, aparecer e falar, um imaginário que se estende por toda a cadeia de produção e de consumo material-simbólico dos tecidos. Tal mundo se expõe no passeio noturno e, em contraposição ao que se manifesta nas passarelas do shopping e em suas vitrines, surge a moça vestida à moda antiga na altíssima murada externa que separa o Shopping da linha de trem. Lá do alto e contra o céu escuro, pergunta pelo bairro já fora da vista e pelos seus costumes mais afinados a um mundo de artesãos e clientes de consumo modesto. 
Esse traço de memória introduz o tema que define a direção da caminhada quando saímos do shopping (emblema do presente) rumo à Casa do Povo (emblema de um outro tempo). Entre um pólo e outro, a travessia exige uma alteração na forma de compor a cena que, nas ruas, tem de se constituir a partir de um conflito de apropriações do espaço, dentro da tensão que envolve o teatro e o fluxo 'normal' dos passantes e veículos. As duas vertentes devem se atropelar, contaminar-se mutuamente para que funcione bem a ambiguidade de uma fronteira instável, mutante, no entanto ainda presente como fiadora do que se circunscreve como unidade do espetáculo na variedade de suas apresentações. O espectador sabe em que direção e que ações deve seguir; quando se retarda, há o conjunto de estações escalonadas que repõem em pequenas cenas ou numa única figura estática (mulher-manequim) a iconografia e o gesto associados aos fetiches do shopping. A céu aberto, os pólos de atenção e distração do olhar se multiplicam, os movimentos do teatro e do fluxo cotidiano se embaralham como coreografias dissonantes - a do elenco e a dos passantes, incluídas as vozes que vêm do alto dos prédios para marcar a expansão da cena pelo espaço que se percorre. Os pontos de maior de voltagem dessa convivência são o desfile de moda na esquina da Rua José Paulino e a luta entre mulheres num ringue improvisado, momentos em que a cena se impõe com força maior e se afirma com uma intensidade que contrasta com o restante da caminhada e com a chegada a passos lentos, com pausa para reflexão, no hoje desativado TAIB (Teatro de Arte Israelita Brasileiro, no passado, um centro intelectual dinâmico e palco de resistência à ditadura militar). Com fartos sinais de abandono, o TAIB, no andar térreo da Casa do Povo, permanece mergulhado numa penumbra que combina com o tom das falas, efeito que a dança da companhia no quase-final que reaviva o antigo palco não dissolve. Resta um último espasmo de agitação de luz, gesto e som que domina a Casa do Povo em ruínas logo antes de voltarmos para a rua. Lá fora, temos a despedida impactante, pontuada pelo re-encontro com as mulheres-manequim a evocar o seu fim de linha na cadeia produtiva (em outro plano, compõem a figura das atrizes-entulho na porta da casa de cultura desativada), sucata depositada de forma desordenada numa caçamba que nos lembra aquela mesma entropia cristalizada na morte do rio, de modo a selar o princípio comum inscrito no trajeto dos dois espetáculos onde o espaço significou o tempo, aqui em Bom Retiro trabalhado pela cena que revolveu camadas de uma história submersa pela consolidação da sociedade de consumo e das alienações e deserções culturais 
que lhe são correlatas. Sem o espírito de cidadania que lhe dá fundamento, atrelada à circulação da cultura aos imperativos do shopping center, o teatro se faz ruína e exige o gesto de invenção radical que torne imperativo o seu revigoramento.

\section{Comentário}

Dentro desta semelhança de princípios que salientei na relação entre estes dois espetáculos excepcionais, há uma diferença. O primeiro compõe um paralelismo no qual é fundamental a não identidade entre e o sítio escolhido como ponto focal de um diagnóstico histórico referido à cidade (e sua mitologia do progresso) e o mundo da fábula vivida pelas personagens cujo ponto focal é de outra ordem e tem como centro outro lugar, de modo que o movimento comum em direção à catástrofe se constrói e se desvela a partir desta não identidade que torna mais consistente o efeito de singularização desejado, e potencializa o valor poético e cognitivo da encenação. $O$ segundo inscreve a cena no próprio sítio urbano que, de partida, é o ponto focal de sua reflexão, de modo que a cena se constrói através da apropriação de um lugar que se identifica com o referente instituído pela fala e pela ação dramática, claro que de uma forma que não se confunde com a ideia de autenticidade de locação própria a um filme neorrealista e a seus desdobramentos no cinema moderno; afinal, o teatro é partilha de uma zona de risco que reúne atores e plateia no mesmo espaço, aqui agora, uma condição potencializada e dramatizada pelos trabalhos em pauta. Neste sentido, o que me interessa nesta nota final é apontar o que julgo estar implicado no fato de que o movimento em direção à catástrofe esteja marcado por esta identidade entre a cena (instituída pelos atores) e a locação. De um lado, tal convergência é altamente produtiva, pois oferece uma âncora capaz de ajustar o teor fragmentário do texto ao dinamismo e às tensões notáveis da mise-en-scène, como bem mostram os seus momentos de alta voltagem que se apóiam neste curto-circuito (penso no desfile de modas na esquina); de outro, há momentos em que uma ou outra fala auto expositiva da condição do(a) personagem se alonga e parece travar o jogo, talvez porque colada demais no que está à vista (penso na figura do excluído e sua pedra).

O comentário é breve, a questão é longa. E, como se sabe, nos remete a toda uma vertente - a que mais me interessa no teatro contemporâneo feito em São Paulo - cujo vigor se apoia na pluralidade dos grupos empenhados na renovação estética articulada ao debate político que envolve o estatuto das artes cênicas na sociedade. 
Tais grupos têm concebido experiências distintas de interação direta com o espaço urbano ou com o cinema, variadas estratégias de expansão da cena e de sua apropriação dos logradouros e do próprio dinamismo da cidade. Da mesma forma, o cinema documentário, por sua vez, tem avançado no reconhecimento prático e estilístico da teatralização implicada em seus procedimentos aptos a dissolver as fronteiras tradicionais entre os gêneros (ficção, documentário). Neste cruzamento, é toda uma tônica da cultura contemporânea às voltas com o problema da representação que está em debate. Continuemos. 